\title{
Analysis of Life Cycle Cost in Developing the Capital City of East Bogor Regency
}

\author{
Rizal Kurniyawan ${ }^{1}$, Pungky Dharma Saputra ${ }^{2}, \mathrm{Safri}^{3}$, Ridwan Saputro ${ }^{4}$ \\ $\left\{\right.$ rizal@student.tau.ac.id $\left.{ }^{1}\right\}$ \\ School of Engineering \& Technology, Tanri Abeng University, Jakarta, Indonesia ${ }^{1,2,4}$ \\ Faculty of Military Engineering, Indonesia Defense University, Bogor, Indonesia ${ }^{2}$ \\ Faculty of Science and Technology, Institut Sains dan Teknologi Al-Kamal, Jakarta, Indonesia ${ }^{3}$
}

\begin{abstract}
Bogor Regency is the most populous area in West Java. Currently, it is facing the problem of increasing population, decreasing agricultural area, and community dissatisfaction with government services. The expansion of the Bogor Regency into the East Bogor Regency is a demand for the formation of a new autonomous regency. However, it is necessary to conduct a financial feasibility study which is involving the government and the private sector in investing in the development of this new regency and its capital city. This research is focusing on calculating the life cycle cost and finding the optimum investment scheme to provide benefits for both parties. The life cycle cost method was used to analyze initial costs, operational and maintenance costs, and revenue to assess the feasibility of this project and then evaluating the scenario of sharing. The capital city of East Bogor regency is planned to be developed in the Jonggol area by developing transportation infrastructure, micro business, government area, housing, and tourism based on smart city. The results of the analysis show that the optimum Net Present Value (NPV) is IDR27,488,111,287,722.20, the Benefit-Cost Ratio (BCR) is 4.28 and the Internal Rate of Return (IRR) is $17.97 \%$ with private sharing for initial costs is $60 \%$, for operational and maintenance costs is $50 \%$ and $60 \%$ for revenue. The evaluation results can become government considerations in making the decision.
\end{abstract}

Keywords: Life cycle cost; investment; capital city; east bogor regency

\section{Introduction}

Bogor Regency is one of the regencies in West Java Province and Cibinong is the center of government [1]. Bogor Regency plays a role in three strategic functions, firstly as a buffer zone for DKI Jakarta, secondly as a conservation water area for Jakarta, and third as an agriculture development area [2]. Meaning, Bogor Regency is the most important area.

Bogor Regency is a large area and population [1]. Currently, it is facing complex problems in terms of the range control and distribution of development. The development gap due to economic growth in the numbers of the area has created welfare problems [3]. The background of the expansion of the Bogor Regency into the East Bogor Regency is the acceleration of area development. In line with the problems, regional development is based on several things such as growth, expansion, sustainability with economic and social considerations [4]. This is based on the desire to improve people's welfare, improve public services, increase regional competitiveness, and realize good governance [3]. According to the results of the analysis of the indicators for the technical requirements of the area's expansion shows that East Bogor Timur 
can separate from Bogor Regency. East Bogor has a very capable value to organize regional autonomy with the value of 420 [3]. The new autonomous region will combine 7 subdistricts in one area. And Jonggol subdistrict will be a new capital city.

In developing Jonggol as the capital city of East Bogor Regency, it is recommended to conduct a financial feasibility analysis with the life cycle cost method to generate an optimal output. Life cycle cost (LCC) is a method to evaluate project cost [5]. Hence, it is an important thing in decision making [6]. This analysis is used throughout the life of the project, starting from the concept to project completion [6]. Initial costs, operation \& maintenance costs, and revenues are the component of life cycle cost itself [5], [7]. Investation period, interest rate, and inflation are the factors that have a high correlation in affecting life cycle cost [7]. In calculation, it is also considered a public-private partnership to assist the government in providing infrastructure and involving the private sector in development [8].

In supporting the development of East Bogor Regency, it is necessary to conduct a financial analysis to determine its feasibility. This research focuses on the life cycle cost analysis to evaluate the financial feasibility of developing Jonggol as the capital city of East Bogor regency. This evaluation can be a consideration for the government in deciding the development of Jonggol as the capital of East Bogor Regency.

\section{Method}

The first step in this research study was to identify the problems. The second step was to conduct a literature review on how to develop a city design. Afterward, financial analysis of the proposed design concept using the life cycle cost analysis method was conducted to obtain the expected IRR and benefit both parties [8]-[11]. The combination scenario would be simulated to reach the IRR which is profitable for both parties in life cycle cost analysis, which consists of initial cost + operation and maintenance cost + revenue sharing. Before the simulation was started, the affecting factor to life cycle cost calculation should be considered such as interest rate and inflation (see Table 1).

Table 1. Factors affecting the life cycle cost calculations

\begin{tabular}{lclc}
\hline \multicolumn{1}{c}{ Factor } & Value & \multicolumn{1}{c}{ Note } & Reference \\
\hline Interest Rate & $4.25 \%$ & Interest Rate in 2020 & Bank of Indonesia \\
Inflation & $4.83 \%$ & Inflation Rate for past 5 years & Bureau of Statistics \\
Inflation in Transportation Sector & $3.49 \%$ & Inflation Rate for past 5 years & Bureau of Statistics \\
Inflation in Tourism Sector & $4.17 \%$ & Inflation Rate for past 5 years & Bureau of Statistics \\
Inflation in Property Sector & $4.38 \%$ & Inflation Rate for past 5 years & Bureau of Statistics \\
Inflation in Industrial Sector & $4.38 \%$ & Inflation Rate for past 5 years & Bureau of Statistics \\
\hline
\end{tabular}

\section{Results and Discussion}

\subsection{Design and Development}

Jonggol is one of the districts in Bogor Regency which has a lot of potential. Hence, Jonggol is very suitable to be developed into a capital city of East Bogor Regency. Its area is close to Cibubur's economic area which is growing rapidly. The development is based on the needs of a 
city with social and economic considerations [8]. The design and development of Jonggol as the capital city of East Bogor Regency begins with a functional analysis using a FAST diagram which is shown in Figure 1.

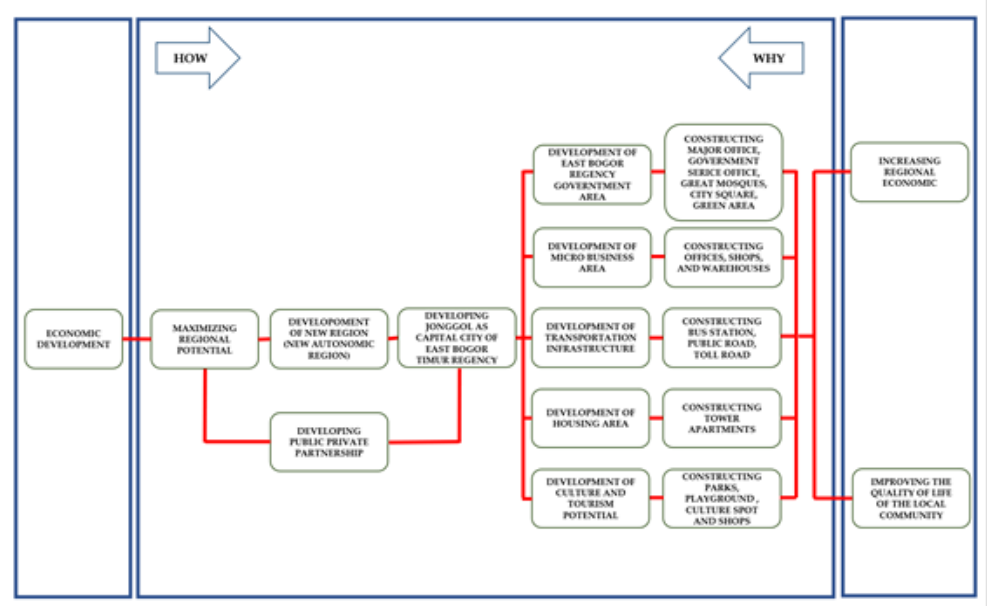

Fig. 1. FAST diagram design and development of capital city of east Bogor regency

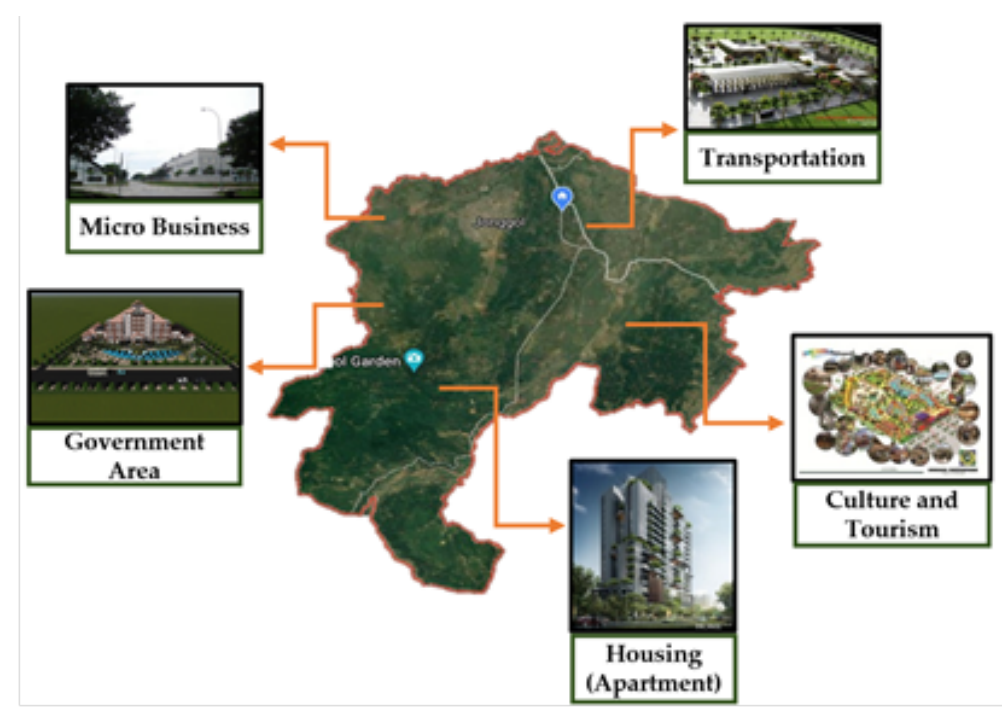

Fig. 2. Design and development of the capital city of east Bogor regency

The main objectives of developing the city are to improve the regional economy and to improve the quality of life of the local community, considering that Jonggol is very far from the current capital city of Bogor Regency. The total development area is 459,071.77 m2 (See Table 2.). The development plan is divided into five main sectors which are important in the development of the city. They are the transportation sector, micro-business area, government area, culture, and tourism sector. Bus stations, public roads, and toll roads will be developed in 
the transportation sector. Offices, shops, and warehouses will be built to support the microbusiness sector. Preparation of governance by building major office, government service offices, great mosques, city square, and green area. 4 tower apartments are also prepared for housing. The culture and tourism sector are also developed by build parks, playgrounds, culture spots, and shops. The location of the development is described in Figure 2.

Table 2. Design and development in the area of the capital city of east Bogor regency

\begin{tabular}{clrl}
\hline No & Development & \multicolumn{1}{c}{ Area (m2) } & \multicolumn{1}{c}{ Information } \\
\hline 1 & Transportation & $32,574.00$ & Bus station, public road, toll road \\
2 & Micro Business & $107,662.00$ & Offices, shops, and warehouses \\
3 & Government Area & $96,775.89$ & Mayor office, government service office, great \\
& & & mosque, city square, and green area \\
4 & Housing (Apartment) & $93,600.00$ & 4 tower apartments, 13 stories \\
5 & Culture and Tourism & $128,459.88$ & Parks, playgrounds, cultural spot, and shops \\
\hline \multicolumn{2}{c}{ Total Development Area } & $459,071.77$ & \\
\hline
\end{tabular}

\subsection{Life Cycle Cost Analysis}

According to analysis, transportation sector initial cost is IDR 7,906,764,000,000.00, micro-business sector initial cost is IDR 534,686,873,277.00, government area initial cost is IDR $1,159,838,000,000.00$, housing sector initial cost is IDR $1,004,369,000,000.00$, culture and tourism sector initial cost is IDR $287,921,461,234.00$ and the total of initial cost is IDR $10,893,579,334,551.00$. These are the funds that must be invested to develop the city. Land acquisition cost is the main component in initial cost [7]. And another cost is provided base on the function of each sector [7]; for instance, the transportation sector including bus stations, public roads, toll roads, and supporting infrastructure facilities. In the micro-business area, this will include offices, shops, and warehouses. The government area will consist of Mayor's offices, government service offices, and city icons like city squares, green areas, and a great mosque. In the housing area, this will include the construction of 4 tower apartments. Finally, cultural and tourism development such as parks, playgrounds, cultural spots, and shops area are including in the initial cost. Detail initial cost is shown in Table 3.

Table 3. Total costs and revenue 30 years' time period

\begin{tabular}{clrrr}
\hline No & Development & $\begin{array}{c}\text { Initial Cost } \\
\text { (In Millions) }\end{array}$ & $\begin{array}{c}\text { Operational \& } \\
\text { Maintenance Cost } \\
\text { 30 Years (In } \\
\text { Millions) }\end{array}$ & $\begin{array}{c}\text { Revenue 30 Years } \\
\text { (In Millions) }\end{array}$ \\
\hline 1 & Transportation & IDR 7,906,764.00 & IDR 234,156.15 & IDR 55,490,760.16 \\
2 & Micro Business & IDR 534,686.87 & IDR 1,331,208.66 & IDR 6,500,253.41 \\
3 & Government Area & IDR 1,159,838.00 & IDR 4,282,992.47 & IDR 23,501,316.73 \\
4 & Housing (Apartment) & IDR 1,004,369.00 & IDR 525,178.20 & IDR 25,477,628.89 \\
5 & Culture and Tourism & IDR 287,921.46 & IDR 708,889.90 & IDR 6,018,002.11 \\
\hline & \multicolumn{1}{c}{ Total } & IDR 10,893,579.33 & IDR 7,082,425.37 & IDR 116,987,961.30 \\
\hline
\end{tabular}

Operational and maintenance cost was calculated base on benchmarking function in each development sector [7]. Investment is planned for 30 years; hence the total operational \& maintenance costs are also calculated along the investment period. The total of operational and maintenance cost for transportation sector is IDR 234,156,145,059.59, for micro-business sector 
is IDR 1,331,208,664,914.40, for the government area is IDR 4,282,992,466,087.15, for housing sector is IDR525,178,198,368.64, for the culture and tourism sector is IDR $708,889,897,358.53$ and the total is IDR 7,082,425,371,788.31. Detail operational \& maintenance cost along investment period is shown in Table 3.

The revenue calculation was based on the results of selling price, rental price, goods production, and services [7]. The total of revenue for transportation sector is IDR $55,490,760,160,665.30$, for micro business sector is IDR $6,500,253,411,658.07$, government area is IDR 23,501,316,731,457.50, housing sector is IDR 25,477,628,885,480.60, culture and tourism is IDR 6,018,002,113,464.79, and the total revenue is IDR 116,987,961,302,726.00. Detail revenue along investment period is shown in Table 4.

Table 4. The result of the life cycle cost analysis before sharing

\begin{tabular}{clrrrr}
\hline No & \multicolumn{1}{c}{ Development } & $\begin{array}{c}\text { Initial Cost (in } \\
\text { Millions) }\end{array}$ & IRR & NPV (In Millions) & BCR \\
\hline 1 & Transportation & IDR 7,906,764.00 & $11.92 \%$ & IDR 19,896,623.76 & 3.48 \\
2 & Micro Business & IDR 534,686.87 & $15.42 \%$ & IDR 1,999,062.44 & 2.68 \\
3 & Government Area & IDR 1,159,838.00 & $11.92 \%$ & IDR 8,259,904.35 & 3.48 \\
4 & Housing (Apartment) & IDR 1,004,369.00 & $38.43 \%$ & IDR 11,226,760.31 & 9.90 \\
5 & Culture and Tourism & IDR 287,921.46 & $28.94 \%$ & IDR 2,338,692.74 & 4.66 \\
& All Development & IDR 10,893,579.33 & $17.72 \%$ & IDR 43,721,043.61 & 4.06 \\
\hline
\end{tabular}

Life cycle cost calculation in each sector shows a good result as shown in Table 4. All IRR values are greater than MARR, all NPV values are positive and all BCR values are more than 1. The results of the total development calculation also show good results with IRR value $=$ $17.72 \%$, positive NPV value $=$ IDR43,721,605,430.50 and $\mathrm{BCR}$ value $=4.06$. In other words, the development of the whole city development is feasible.

Table 5. Perspective of the private investor on the revenue component

\begin{tabular}{cccccccc}
\hline \multirow{2}{*}{ Scenario } & \multicolumn{3}{c}{ Private Sharing } & & & NPV & BCR \\
\cline { 2 - 4 } & $\begin{array}{c}\text { Initial } \\
\text { Cost }\end{array}$ & $\begin{array}{c}\text { O\&M } \\
\text { Cost }\end{array}$ & Revenue & IRR & & & \\
\hline 26 & $50 \%$ & $100 \%$ & $100 \%$ & $35.29 \%$ & IDR 50,647,745.49 & 6.55 \\
27 & $50 \%$ & $80 \%$ & $100 \%$ & $35.71 \%$ & IDR 51,382,821.08 & 7.13 \\
28 & $60 \%$ & $70 \%$ & $80 \%$ & $23.91 \%$ & IDR 38,707,018.32 & 5.25 \\
29 & $60 \%$ & $60 \%$ & $70 \%$ & $20.96 \%$ & IDR 33,097,564.80 & 4.79 \\
30 & $60 \%$ & $50 \%$ & $60 \%$ & $17.97 \%$ & IDR 27,488,111.29 & 4.28 \\
\hline
\end{tabular}

The research analyzes 30 scenarios. However, there were only 5 final scenarios that combine initial cost, operational \& maintenance cost, and revenue sharing with the private sector. Scenario 26 generate Net Present Value (NPV) is IDR50,647,745,487,282.00, the Benefit-Cost Ratio (BCR) is 6.55 and the Internal Rate of Return (IRR) is $35.29 \%$ with private sharing for initial costs is $50 \%$, for operational and maintenance costs is $100 \%$ and $100 \%$ for revenue. Scenario 27 generate Net Present Value (NPV) is IDR51,382,821,078,694.00, the Benefit-Cost Ratio (BCR) is 7,13 and the Internal Rate of Return (IRR) is $35.71 \%$ with private sharing for initial costs is $50 \%$, for operational and maintenance costs is $80 \%$ and $100 \%$ for revenue. Scenario 28 generate Net Present Value (NPV) is IDR38,707,018,318,629.70, the Benefit-Cost Ratio (BCR) is 5.25 and the Internal Rate of Return (IRR) is $23.91 \%$ with private 
sharing for initial costs is $60 \%$, for operational and maintenance costs is $70 \%$ and $80 \%$ for revenue.

Scenarios 26 and 27 do not provide benefits for the government because the government does not get revenue from development, so this investment scheme is not recommended. Scenario 28 also does not give any profit because the value of sharing for operations \& maintenance and the revenue is still too high. According to the Ministry of Finance regulation in 2012, the percentage of private sharing for initial cost ranges from $40 \%$ to $60 \%$, operational \& maintenance costs ranges from $40 \%$ to $60 \%$, and revenues range from $60-80 \%$ [12].

Based on the description, scenarios 29 and 30 fulfill the requirements, because the percentage of initial cost-sharing for private is $60 \%$, and this has been applied in many countries [11]. The percentage cost of operation and maintenance cost and revenue have also met the regulation of the minister of finance. For scenario 29 , with private sharing for initial costs is $60 \%$, for operational and maintenance costs is $60 \%$ and $70 \%$ for revenue has generated Net Present Value (NPV) is IDR33,097,564,803,175.90, the Benefit-Cost Ratio (BCR) is 4.79 and the Internal Rate of Return (IRR) is $17.97 \%$.

However, to ease the government on operational and maintenance costs, $50 \%$ sharing is applied. Because, the main principle of the public-private partnership should generate mutual benefit [8], so not only the private sector but also the government will get a benefit. Scenario 30 accommodates the requirements and it is considered beneficial for the government by applying private sharing for initial costs is $60 \%$, for operational and maintenance costs is $50 \%$ and $60 \%$ for revenue. The analysis generates Net Present Value (NPV) is IDR27,488,111,287,722.20, the Benefit-Cost Ratio (BCR) is 4.28 and the Internal Rate of Return (IRR) is $17.97 \%$. The results of this analysis are feasible and beneficial for both parties. The detail of scenarios is shown in Table 5. above.

\section{Conclusion}

Life cycle cost analysis results show that the initial cost for developing Jonggol as the capital city of East Bogor Regency is IDR10,893,579,334,511.00. The proposed private investment sharing for initial costs is $60 \%$, for operational and maintenance costs is $50 \%$ and $60 \%$ for revenue with the Net Present Value (NPV) is IDR27,488,111,287,722.20 the BenefitCost Ratio (BCR) is 4.28 and the Internal Rate of Return (IRR) is $17.97 \%$. The life cycle cost analysis results can become government consideration in deciding to develop Jonggol as the capital city of East Bogor Regency. This research needs to be developed again to find the advantages and disadvantages of public-private partnerships. Furthermore. It is also necessary to develop institutional cooperation schemes starting from the design, construction, and operation period.

\section{References}

[1] BPS - Statistics of Bogor Regency, "Bogor Regency in Figures 2019”. Bogor: BPS - Statistics of Bogor Regency, 2020.

[2] E. T. Dani, S. R. P. Sitorus, dan K. Munibah, "Analisis Penggunaan Lahan dan Arahan Pengendalian Pemanfaatan ruang di Kabupaten Bogor”. Tata Loka, Volume 19. 40 -52, 2017. 
[3] A. Nurhasanah, "Kelayakan dan Strategi Pengembangan Wilayah dalam Wacana Pembentukan Daerah Otonom Baru Bogor Timur". Tesis. Program Studi Ilmu Perencanaan Pembangunan Wilayah dan Perdesaan. Sekolah Pascasarjana. Institut Pertanian Bogor. 2017.

[4] M. A. Berawi, P. Miraj, P., A. R. B. Berawi, R. Agdhitya, "Increasing Added Value for the New City of Walini Through Infrastructure Project Development", International Journal of Technology. Volume 8(6), pp. 1141-1149, 2017

[5] M. A. Berawi, P. L. Wicaksono, Gunawan, P. Miraj, H. A. Rahman, "Life Cycle Cost Analysis of the Transit-oriented Development Concept in Indonesia", International Journal of Technology, Volume 10(6), pp. 1184-1193, 2019.

[6] S.K.P. Fuller, R. Stephen, 1996, "Life Cycle Costing Manual for the Federal Energy Management Program", Gaithersburg: National Institute of Standards and Technology, 1996.

[7] M. A.Berawi, A. Nabila, Gunawan., P. Miraj, H. A. Rahman, A.R.B. Berawi, "Analysis of Life Cycle Cost and Public-Private Partnership in the Development of Walini City as Technology Park", International Journal of Technology, Volume 9(7), pp. 1469-1479, 2018.

[8] M. A. Berawi, "Public-Private Partnership: Generating Mutual Benefits for Stakeholders", International Journal of Technology. Volume 10(1), pp. 1-4, 2019

[9] H. Z. Rahman, M. A. Berawi, B. Susantono, B., P. Miraj, J. S. Petroceany, and R. Maya, "Investigation of an operation and maintenance framework in the railway industry: a case study of the makassar-parepare", International Journal of Technology, 9(3), 549-557, 2018.

[10] M. A. Berawi, B. E. Ibrahim, and P. Miraj, "Developing A Conceptual Design of Transit-Oriented Development To Improve Urban Land Use Planning", Journal of Design and Built Environment(1), 2019

[11] M. A. Berawi, T. E Muljono, P. Miraj, and Gunawan, "Developing Port-City Conceptual Design to Improve Regional Industry Competitiveness", First International Conference of Construction, Infrastructure, and Materials. IOP Conf. Series: Materials Science and Engineering, 650, 012015, 2019.

[12] Peraturan Menteri Keuangan Nepublik Indonesia No. 223/PMK.01/2012 tentang Pemberian Dukungan Kelayakan Atas Sebagian Biaya Konstruksi pada Proyek Kerja Sama Pemerintah dengan Badan Usaha dalam Penyediaan Infrastruktur 